\title{
Correction to: David Whyte: Ecocide: Kill the Corporation Before It Kills Us
}

\section{Manchester University Press, Manchester, UK, 2020, xvi+222 pp, ISBN 978-1-5261-4698-4 (PB)}

\section{Teresa Fajardo $^{1}$}

Published online: 9 June 2021

(c) Springer Nature B.V. 2021

\section{Correction to: Critical Criminology https://doi.org/10.1007/s10612-021-09566-0}

In the original publication, the author's name, "David Whyte," in the article title was incorrectly published as "David White."

The correct article title is "David Whyte: Ecocide: Kill the Corporation Before It Kills Us. Manchester University Press, Manchester, UK, 2020, xvi+222 pp, ISBN 978-1-52614698-4 (PB)."

The original article has been corrected.

Publisher's Note Springer Nature remains neutral with regard to jurisdictional claims in published maps and institutional affiliations.

The original article can be found online at https://doi.org/10.1007/s10612-021-09566-0.

1 Department of Public International Law and International Relations, University of Granada, Granada, Spain 